\title{
UTILIZATION OF WATER CRESS (NASTURTIUM OFFICINALE L.) IN NOBLE CRAYFISH (ASTACUS ASTACUS) FEEDING
}

\author{
E. D'AGARO
}

Dipartimento diScienzeAnimali, Università diUdine, Vias. Mauro2 33010Pagnacco(UD), Italy. E-Mail: dagaro@dspa.uniud.it

Reçu le 6 juin 2005

Accepté le 11 octobre 2005

Received June 6, 2005

Accepted October 11, 2005

\begin{abstract}
Juvenile Astacus astacus (initial b.w.: $0.98 \pm 0.06 \mathrm{~g}$ ) were cultured (30 crayfish $/ \mathrm{m}^{2}$ ) in 200 l tanks for 69 days. The experimental design was composed of three treatments as follows: control diet (C) (crude protein: $28.4 \%$ of the total dried matter, "DM"; ether extract: $6.22 \%$ DM), water cress (W) (crude protein: $20.7 \%$ DM; ether extract: $1.9 \% \mathrm{DM}$ ) and control diet + water cress $(\mathrm{C}+\mathrm{W})$ with thee replicates per treatment. Relative growth rate improved significantly $(P<0.05)$ in crayfish fed $C+W(+110 \%)$ compared to W $(+43 \%)$ and the control diet $(+36 \%)$. Gross protein and lipid retentions of the treatment $\mathrm{C}+\mathrm{W}$ were significantly higher than the control diet and water cress fed alone. At the end of the experiment, a higher survival rate of $A$. astacus was observed $(P<0.05)$ in the treatment $\mathrm{C}+\mathrm{W}(67 \%)$ and $\mathrm{C}(71 \%)$ compared to the W (58\%). These results suggest that the plant water cress (Nasturtium officinale) can be used as supplemental food in noble crayfish feeding.
\end{abstract}

Key-words: Astacus astacus, Nasturtium officinale, nutrition.

\section{UTILISATION DU CRESSON (NASTURTIUM OFFICINALE L.) DANS L'ALIMENTATION DE L'ÉCREVISSE NOBLE (ASTACUS ASTACUS)}

\section{RÉSUMÉ}

Des juvéniles d'Astacus. astacus (poids initial : 0,98 $\pm 0,06 \mathrm{~g}$ ) ont été élevés (30 écrevisses $/ \mathrm{m}^{2}$ ) dans des aquariums de 200 I pendant 69 jours. Le protocole expérimental a consisté en trois traitements comme suit : régime de contrôle (C) (protéines brutes : 28,4 \% des Matières sèches totales, "MS "; extraits à l'éther : 6,22 \% MS), cresson (W) (protéines brutes : 20,7\% MS ; extraits à l'éther : 1,9\% MS) et régime de contrôle + cresson $(C+W)$ avec trois réplicats par traitement. Le taux de croissance relative a augmenté significativement $(P<0,05)$ chez les écrevisses alimentées avec $\mathrm{C}+\mathrm{W}(+110 \%)$ par comparaison avec celles alimentées avec W (+ $43 \%)$ et celles ayant le régime de contrôle $(+36 \%)$. Les rétentions de protéines grasses et de lipides du traitement $\mathrm{C}+\mathrm{W}$ ont été significativement plus importantes qu'avec le régime de contrôle ou l'alimentation unique. A la fin de l'expérimentation, un taux plus élevé de survie d'A. astacus a été observé $(P<0,05)$ pour le traitement $C+W(67 \%)$ et $C(71 \%)$ en comparaison avec W (58\%). Ces résultats suggèrent que le cresson (Nasturtium officinale) peut être utilisé comme complément alimentaire chez l'écrevisse noble.

Mots-clés : Astacus astacus, Nasturtium officinale, nutrition. 


\section{INTRODUCTION}

The water cress is a perennial European plant (Nasturtium officinale), which grows naturally in brooks, ditches and pond margins. It is cultivated in several countries and used as a garnish and a piquant salad. The small floating leaves are rounded, dark green and waxy. The branching stems can spread out for 2-3 cm over the surface. Slender roots hang down from the nodes of the stems. It is a very good oxygenator. It develops many small white flowers over the growing season. Water cress tolerates sun, or partial shade. It is a prolific re-seeder and will re-sow itself yearly. It grows in shallow water in a wide range of conditions and in many sediment types. The plants grow in lakes, ponds and in slow moving water in rivers, canals and streams. It is an important part of lake and river ecosystems. It provides good habitat for many aquatic invertebrates and cover for young fish and amphibians.

A major advantage for the culture of freshwater crayfish is that they eat a wide range of foods that occur naturally in the pond water, including organisms living on detritus and plant material. Several successful crayfish farms grow fodder crops in the ponds prior to flooding. Once the fodder crops are established, the ponds are slightly flooded and the crayfish introduced (O'SULLIVAN, 1995). As an alternative, several plants such as chopped vegetables, lucerne chaffs, lupins and compost are supplied (JONES et al., 2002). Juveniles need small regular feeds while larger animals are fed once a day. Feed is spread around the edges of ponds for the foraging crayfish. The preferred forage to plant for crayfish in USA is rice (Oriza sativa) (REX et al., 1978). Factors to be considered in plant selection include culture system (rotational or single cropping) forage biomass, lodging characteristics and plant growth potential. The nutritive value of a plant is dependent on several factors including the chemical composition, the nutrient digestibility and the lack of toxicity. High growth rates of noble crayfish have been related to a diet containing high percentages of linoleic (18:2n-6) and eicosapentaenoic (20: $5 n-3)$ fatty acids (D'AGARO and LANARI, 2001).

Factors which are considered when choosing pelletized diets include cost, absence of pesticides and herbicides, ease of application, food conversion ratio, shelf life, particle size, attractants and palatability, the breakdown period, potential for pollution and the best time of day for feeding (D'AGARO and LANARI, 2004). MUZINIC et al. (2004) reported the total replacement of fish meal with a combination of soybean meal and brewer's grains with yeast in diets of juvenile Australian red claw. In contrast, FERNANDEZ and PUCHAL (1979) reported nutritional deficiencies observed in crustaceans fed exclusively with artificial diets.

These deficiencies can be related to active factors or growth-promoting substances such as lecithin and/or cholesterol (CONKLIN et al., 1980).

The objective of the present study was to investigate the effects of supplementation of a standard diet with the plant water cress on noble crayfish growth performance.

\section{MATERIAL AND METHODS}

The growth trial was performed in the aquaria at the Department of Animal Science, University of Udine (Pagnacco, Italy). Summerling Astacus astacus were bought in Germany (Ausburg) at the First Bavarian Crayfish Hatchery. The plant water cress was collected weekly in the "Risorgive" wetlands of the Stella river near Udine (Italy). 270 noble crayfish Astacus astacus (initial live weight: $0.98 \pm 0.06 \mathrm{~g}$ ) were randomly allotted in 9 tanks $\left(1 \mathrm{~m}^{2} \times 0.6 \mathrm{~m}\right)$. The experimental design was composed of three treatments as follows: control diet (C) (crude protein: $28.4 \% \mathrm{DM}$; ether extract: 6.2\% DM), water cress (W) (crude protein: $20.7 \% \mathrm{DM}$; ether extract: $1.9 \% \mathrm{DM})$ and control diet + water cress $(C+W)$ with thee replicates per treatment. Water cress was supplied as bunches of fresh vegetation. 
Crayfish were fed ad libitum for $69 \mathrm{~d}$. Temperature, dissolved oxygen and other water parameters were measured weekly $\left(\mathrm{T}: 15.1^{\circ} \mathrm{C} ; \mathrm{O}_{2}: 7.2 \mathrm{mg} / \mathrm{l} ; \mathrm{pH}: 7.5 ; \mathrm{N}-\mathrm{NH}_{4}: 0.05 \mathrm{mg} / \mathrm{l}\right.$; $\mathrm{N}-\mathrm{NO}_{2}: 0.01 \mathrm{mg} / \mathrm{l} ; \mathrm{N}^{-N_{3}}: 29.9 \mathrm{mg} / \mathrm{l}$ and total hardness: $133 \mathrm{mg} \mathrm{l}^{-1}$ ) (APHA, 1980). Each tank contained a porous stone aerator and received a continuous flow of water. Mortality rate was recorded at each weighing and crayfish were weighed once a fortnight. Crayfish were fed by automatic feeders 6 times daily. The daily feed allotment was equally divided into morning, afternoon and night. Uneaten pellets were collected daily before 9 a.m.. Feed allotment (\% b.w.) was adjusted weekly according to the expected weight. Pellets were manufactured using a meat mincer. A photoperiod of $12 \mathrm{~h}$ light daily was maintained during the experiments. During the trials, samples of the diet and water cress were collected for proximate analysis (A.O.A.C., 1990) and the gross energy concentration was determined by adiabatic bomb calorimeter. At the beginning (10 animals) and at the end (five animals per tank) were sampled for the body composition analysis. The experimental data recorded during the growth trial was subjected to one-way analysis of variance, GLM procedure, with the comparison between means being realised with the Dunnett's multiple range test (SAS 1989).

\section{RESULTS}

The composition and chemical analysis of the control diet and water cress are reported in Table I and II, respectively.

The diet chosen for the experiment was made of typical feed ingredients such as fish and soybean meals and lucerne concentrate. The chemical composition of the diet was in line with the standard values required for crayfish during the growing phase. Protein, lipid and gross energy contents were lower in the water cress while crude fibre and ash values were higher compared to the control diet.

The primary focus of the present work was to compare the effects of the water cress (Nasturtium officinale L.), used as a supplemental feed of a pelleted diet, on noble crayfish growth performance. Growth parameters and nutrient body retentions are reported in Table III.

Results of the present study showed that the growth rate of $A$. astacus fed a pelleted diet and water cress was greater to that of animals fed the control diet and/or water cress alone. Relative growth rate ((final b.w. - initial b.w.)/(initial b.w.)) (\%) was significantly

\section{Table I}

\section{Composition of the experimental diet.}

Tableau I

Composition des régimes expérimentaux.

\begin{tabular}{lcrc}
\hline \multicolumn{1}{c}{ Variables } & & \multicolumn{2}{c}{ Treatments } \\
\hline Dry matter & $\%$ & Diet & Water cress \\
Crude protein & $\%$ d.m. & 93.8 & 9.1 \\
Ether extract & \% d.m. & 28.4 & 20.7 \\
Crude fibre & $\%$ d.m. & 6.2 & 1.9 \\
Ash & \% d.m. & 5.7 & 16.5 \\
N-free extract & \% d.m. & 57.1 & 20.0 \\
Gross energy & MJ/kg d.m. & 18.7 & 40.8 \\
\hline
\end{tabular}


Table II

Proximate analysis of the experimental diet and water cress.

Tableau II

Analyse immédiate des régimes expérimentaux et du cresson.

\begin{tabular}{lc}
\hline \multicolumn{1}{c}{ Ingredients $\mathbf{( g / k g )}$} & Diet \\
\hline Soybean meal & 170 \\
Lucerne concentrate & 150 \\
Cooked wheat starch & 350 \\
Fish meal & 250 \\
Maize oil & 40 \\
Na alginate & 20 \\
Vit-min mix & 20 \\
\hline
\end{tabular}

Table III

Initial and final body weight, RGR, GPR, GLR and survival of crayfish A. astacus.

Tableau III

Poids corporel initial et final, taux de croissance relative (RGR), rétention de protéines grasses (GPR), rétention de lipides gras (GLR) et survie de l'écrevisse A. astacus.

\begin{tabular}{lcccc}
\hline \multicolumn{1}{c}{ Variables } & D & W & D + W & $\begin{array}{c}\text { Err. Var. } \\
\text { (6 d.f.) }\end{array}$ \\
\hline Initial weight (g) & 1.01 & 1.0 & 0.93 & 0.0020 \\
Final weight (g) & $1.39^{\mathrm{b}}$ & $1.44^{\mathrm{b}}$ & $1.85^{\mathrm{a}}$ & 0.088 \\
$\mathrm{RGR}^{1}(\%)$ & $36 \mathrm{~b}$ & $43^{\mathrm{b}}$ & $110^{\mathrm{a}}$ & 1277 \\
$\mathrm{GPR}^{2}(\%)$ & 37.6 & 44.0 & 98.9 & 5.2 \\
$\mathrm{GLR}^{3}(\%)$ & 54.0 & 61.0 & 123.0 & 3.7 \\
Survival (\%) & $71^{\mathrm{a}}$ & $58^{\mathrm{b}}$ & $67^{\mathrm{a}}$ & 269 \\
\hline
\end{tabular}

Means with different superscripts within the same row are significantly different $a, b: P<0.05$ ).

1 RGR: Relative growth rate ((final b.w. - initial b.w)/(initial b.w.)).

2 GPR: Gross Protein Retention, (protein gain, g)/(protein consumption, g) × 100).

3 GPR: Gross Lipid Retention, (lipid gain, g)/(lipid consumption, g) $\times 100$ ).

$(\mathrm{P}<0.05)$ higher in the treatment control diet + water cress $(+110 \%)$ compared with the cress alone $(+43 \%)$ and the control diet $(+36 \%)$. Gross protein and lipid retentions of diet + water cress were significantly higher than the control diet and/or water cress fed alone. At the end of the experiment, a higher survival rate of $A$. astacus was observed $(\mathrm{P}<0.05)$ in the treatment $\mathrm{C}+\mathrm{W}(67 \%)$ and $\mathrm{C}(71 \%)$ compared to the W $(58 \%)$.

\section{DISCUSSION}

The plant water cress, used in the present study, plays a very important role in the natural ecosystem of "Risorgive" wetlands of the Stella river near Udine (Italy). This location has been recognized as a Special Conservation Area (SAC) according to EU 
Habitat Directive. SBURLINO et al. (1995) listed all the most important plants living in this site: Nasturtium officinale, Myosotis palustris, Cardamine amara, Veronica beccabunga, Mentha aquatica, Veronica anagallis-aquatica, Lythrum salicaria, Caltha palustris and Iris pseudacorus. Conservation plans have started since 2000 for plants and animals in order to save three unique biotypes, which characterize the SAC.

To date, little is known on the crayfish culture using natural vegetation and/or supplemental feed. The main advantage of using natural vegetation is the reduction of the feed cost. Agricultural lands unsuited for growing crops because of improper drainage or inadequate soil types can be used for naturally vegetated ponds. Water can be managed to select for aquatic vegetation over terrestrial species.

Mean final weights of crayfish fed the control diet + water cress were significantly $(P<0.05)$ higher than crayfish fed the control diet and water cress alone. GEDDES et al. (1993) recorded a $22 \%$ increase in growth of Cherax destructor using lucerne hay in comparison to a $25 \%$ protein pelleted diet and WIERNICKI (1984) found that the assimilation efficiency of $P$. clarkii fed elodea (Egera densa) increased when the plant had been decomposed for several weeks. HILL et al. (1993) reported an increase of growth when feeding crayfish on animal food in comparison with a diet based on detritus or primary producers.

Several experimental studies have clearly indicated that the dietary protein and lipid requirement of freshwater crayfish for optimal growth is respectively between $25-30 \%$ and 6-8\% DM (ACKEFORS et al., 1992). Protein and lipid contents of natural feed sources are highly variable ranging from $50-60 \%$ of plankton and macroinvertebrates to $20 \%$ of plants (TACON, 1990). Dietary fibre and anti-nutritional substances are other important factors to be considered in crayfish nutrition. Protein and lipid apparent digestibility coefficients and nutrient efficiency ratios are good indicators of the nutritive value of feeds (BROWN et al., 1990; ILHEU and BERNARDO, 1995). In the present study, protein and lipid retentions of water cress were similar to the control diet. During the growing trial, the supplementation of the water cress to the diet improved significantly the protein and lipid assimilation indices.

Lipid and gross energy contents of the experimental diet were higher than those of the water cress. The different nutritive and energetic value of the two feeds may explain the lower growth and survival rate observed in crayfish fed the water cress alone.

\section{CONCLUSION}

These results suggest that (1) water cress can be used to increase growth and survival in summerling noble crayfish and (2) it can be part of the natural diet of this crayfish species.

\section{REFERENCES}

ACKEFORS H., CASTELL J.D., BOSTON L., RATY P. AND SVENSSON M., 1992. Standard experimental diets for crustacean nutrition research. II. Growth and survival of juvenile crayfish Astacus astacus (Linné) fed diets containing various amounts of protein, carbohydrate and lipid. Aquaculture, 104, 341-356.

A.O.A.C., 1990. Official Methods of Analysis, $15^{\text {th }}$ edition. Association of Official Analytical Chemists (AOAC). Washington, DC.

APHA, 1980. Standard Methods for the Examination of Water and Wastewater, $15^{\text {th }}$ edition. American Public Health Association. Washington, DC. 
BROWN K.M., TAZIK P., HOOE M.L., BLYTHE W.G. 1990. Consumption and apparent dry matters digestibility of aquatic macrophytes by male and female crayfish (Orconectes virilis). Aquaculture, 89, 55-64.

CONKLIN D.E., D'ABRAMO L.R., BORDNER C.E., BAUM N.A., 1980. A successful purified diet for the culture of juvenile lobsters: the effect of lecithin. Aquaculture, 21, 234237.

D'AGARO E., LANARI D., 2001. Fatty acid utilisation in juvenile Astacus astacus fed diets containing different oils. Proc.: Knowledge-based Management of European Native Crayfishes, Poitiers, 13-15 th September 2001, p. 30.

D'AGARO E., LANARI D., 2004. Effects of binders and increasing amounts of water before drying on nutrient leaching and pellet hardness in crayfish diets. Freshwater crayfish, 14, 81-89.

FERNANDEZ R., PUCHAL F., 1979. Studies on compounded diets for Penaeus Kerathurus shrimp. Proc. World Maricult. Soc., 10, 781-787.

GEDDES C.A., SMALLRIDGE M., 1993. Survival, growth and yield of the Australian freshwater crayfish Cherax destructor in extensive aquaculture ponds. Aquaculture, 114, 51-70.

HILL A.M., SINARS D.M., LODGE D.M., 1993. Invasion of an occupied niche by the crayfish Orconectes rusticus: potential importance of growth and mortality. Oecologia, 94, 303-306.

ILHEU M., BERNARDO J.M., 1995. Trophic ecology of red swamp crayfish Procambarus clarkii (Girard) performances and digestibility of plants foods. Freshwater crayfish, 10, 132-139.

JONES P.L., CHAVEZ J.R., MITCHELL B.D., 2002. Production of Australian freshwater crayfish in earthen-based systems using pelleted diets and forage crops as food. Aquacult. Int., 10, 157-175.

MUZINIC L.A., KENNETH R.T., MORRIS A., WEBSTER C.D., ROUSE D.B., MANOMAITIS L., 2004. Partial and total replacement of fish meal with soybean meal and brewer's grains with yeast in practical diets for Australian red claw crayfish Cherax quadricarinatus. Aquaculture, 230, 359-376.

REX H.C., ROMAIRE R.P., AVAULT J.W., 1997. Sustainable aquaculture: crawfish farming. Freshwater crayfish, 11, 587-598.

O'SULLIVAN D.D., 1995. Techniques for semi-intensive culture of freshwater crayfish in Australia. Freshwater Crayfish, 10, 569-582.

SAS, 1989. SAS User's Guide. 4th ed. SAS Institute, Cary, NC, USA.

SBURLINO G., BRACCO F., BUFFA G., GIRELLI L., 1995. Rapporti dinamici e spaziali nella vegetazione legate alle torbiere neutro-alcaline delle risorgive della pianura Padana orientale (Italia settentrionale). Coll. Phytosoc., 2, 286-294.

TACON A.G.I., 1990. Standard Methods for the Nutrition and Feeding of Farmed Fish and shrimp. Argent Laboratories Press, Redmont, Washington.

WIERNICKI C., 1984. Assimilation efficiency by Procambarus clarkii fed Elodea and its products of decomposition. Aquaculture, 36, 203-215. 